\title{
Pannónia keleti része is karoling fennhatóság alatt állt a 9. században?
}

A történettudomány véleménye korábban megoszlott a címben feltett kérdésben (Cs. Sós 1973: 31). A pécsi, kaposszentjakabi és visegrádi ásatások legújabb elemzései azonban bizonyították, hogy Pannónia karoling fennhatóság alá tartozó területe lényegesen nagyobb kiterjedésű volt a korábban feltételezettnél. A fenti kérdésre így már eleve igennel válaszolhatunk. Az alábbiakban azt szeretném megvizsgálni, vannak-e erre további bizonyítékok, különösen a tekintetben, hogy a salzburgi érsekség térítési tevékenysége kiterjedt-e, illetve kiterjedhetett-e a szükebb Balaton-környéki területeken túlra, Pannónia keleti vidékére egészen a Duna és a Dráva vonaláig. A Conversio 13. fejezetében találunk adalékokat arra, hogy Adalwin érsek 865-ben ezen a területen is szentelt templomokat. Ezzel összefüggésben a szöveg saját templommal rendelkező földesurat említ, akinek a neve már 850 körül kiemelt helyen szerepelt.

\section{Unzat - név és származás}

Az Unzat névröl a legtöbb tanulmányban mindössze annyi olvasható, hogy sem germán, sem szláv névként nem azonosítható, hanem a feltételezések szerint talán avar vagy bolgár eredetü lehet. A név viselőjének elsőként WOLFRAM munkája szentel méltó figyelmet (2013).

Liupram, Salzburg érseke 850-ben Pribina „erödített településére” érkezett, hogy Isten anyja, Szüz Mária tiszteletére szentelje az ott emelt templomot, valamint okirattal is véglegesítse egy bizonyos Dominicus nevü pap Pribina szolgálatába és Salzburg egyházi joghatósága alá történő átvételét. A megállapodás létrejötténél tanúként jelen volt Pribina kíséretének 32 tagja, akiket a Conversio név szerint felsorol, Chezil-lel, Unzat-tal és Chotemir-rel kezdődően (Conversio 11., WOLFRAM 2013: 74-75). ${ }^{1}$ Unzat a második helyen áll, közvetlenül Pribina fia után.

\footnotetext{
${ }^{1}$ A tanúk névsorában harmadik helyen szereplő karantán fejedelem, Chotemir többszöri említése a Pribiná-val való szoros kapcsolatra enged következtetni (vö. WOLFRAM 2013: 188, MitTERAUER 1960: 691, 723).
} 
Chezil és Unzat még egyszer szerepel ugyanebben a sorrendben. Cividale evangéliumos könyvében a következő bejegyzés olvasható: Cozil, Uuozet és Margareta. $^{2}$

Unzat harmadik említése a Conversio 13. fejezetében található: Liupram utóda, Adalwin érsek 864 karácsonyán Chezil „újabban Mosapurc-nak nevezett” székhelyére érkezett (Conversio 13., WOLFRAM 2013: 78-79), azt követően több templomot is szentelt. Ezek közül az utolsó a szent Margareta szüz tiszteletére épült templom Spizzun-ban, a szentelés pontos dátuma január 14. A rövid időtartamra tekintettel e templomszentelések csak a Balaton közelebbi környezetében lokalizálhatók.

Az ezután felsorolt templomszentelésekre későbbi időpontban került sor, ami feltételezni engedi, hogy már távolabbi területen található településekről van szó. Ezek között két olyan helység is található, Termperch és Cella, amelyet az arra utaló támpontok egész sora alapján Pannónia délkeleti részén kellene keresnünk. Erre a későbbiekben még részletesen visszatérünk. „Termperch-ben [Adalwin] szent Lőrinc tiszteletére szentelt templomot. [...] Az azt követő időkben is felkereste a területet bérmálás és prédikálás céljából, és ennek során eljutott a Cella nevezetü helyre is, amely Unzat birtoka, $\mathrm{s}$ ahol egy templom várt szentelésre. Ezt [a templomot] szent Péter apostolfejedelem tiszteletére szentelte fel, és saját papot is helyezett oda."

A Chezil és Unzat nevek közös említése nem véletlen. Pribina hozzátartozóiként a 850. évi tanújegyzék élén szerepelnek, és Cividale evangéliumos könyve (vö. WOLFRAM 2013: 188) ugyanabban a sorrendben említi őket. Chezil Pribina idősebb fia, aki a morvák által meggyilkolt apját 860-ban követte a trónon. Habár Unzat származását és hovatartozását tekintve sehol nem találunk adatot, feltételezhető a családi kapcsolat. MITTERAUER szerint Unzat Chezil öccse lehetett. WOLFRAM azonban kételkedik ebben, mivel Chezil és Unzat első említése között 17 év telt el, így kettejük anyja aligha lehetett azonos. Amikor Pribina viszályba keveredett Ratbod-dal (a bajor „keleti tartomány” prefektusával) és a bolgárok országába menekült, magával vitte fiát, Chezil-t is (Conversio 10., WOLFRAM 2013: 72-75). A szöveg feleséget nem említ, hitvese valószínűleg már meghalt. WOLFRAM joggal feltételezi (2013: 188, 280), hogy Unzat Pribina fia lehetett egy olyan avar vagy bolgár asszonytól, akit Pribina a bolgároknál töltött idő alatt,

${ }^{2}$ Adalwin 865. január 14-én Margaretáról nevezett templomot szentelt Spizzunban. „Kézenfekvő, hogy ebben összefüggést lássunk; lehetséges, hogy Margareta Unzat felesége, vagy a két féltestvér közelebbi rokona volt." (MitTERAUER 1960: 723, BETHMANN 1887: 119, WOLFRAM 2013: 188).

${ }^{3}$ E szöveghely arra enged következtetni, hogy Adalwin két, esetleg három alkalommal járt valamely, a Balaton vidékén kívül található területen. Adalwin-t valószínüleg Unzat hívta meg, hogy szentelje fel az arra előkészített templomot. 
a harmincas években vett feleségül (Conversio 10., WOLFRAM 2013: 73). Ezt feltételezve Unzat az első említés idején, 850 körül legfeljebb 16 éves lehetett.

A 850-beli tanújegyzék neveinek nyelvi értelmezése (sorrendben 13 szláv, azt követően 18 germán név) összességében nem jelentett nehézséget, kivéve Unzat nevét. ${ }^{4}$ Ennek megfejtéséhez szeretnék az alábbiakkal hozzájárulni.

A név kéttagú összetett szó, eredetét tekintve hibrid. Az utótag végső soron az iráni $z \bar{a} d \sim z \bar{a} d e$ származéka. A mai irániban a -zāde végződés igen gyakran elöfordul tulajdonnevekben, pl. Hassanzadeh 'Hasszan fia'. A két alakváltozat (azonos jelentéssel) iráni jövevényszóként megtalálható a türk nyelvekben a Nyugaton beszélt oszmán-töröktől egészen a türk nyelvterület keleti részén — föként a mai kínai Xinjiang tartományban (Kínai Turkesztánban) — élő ujgurig egyrészt köznévi 'személy, (rangos) személyiség' jelentésben, másrészt tulajdonnévként is. A -zat írott alak a szóvégi - $t$-vel például a mai törökben és ujgurban szabályosan jeleníti meg a szóvégi mássalhangzó zöngétlenedését, amelyre a -de végzödésủ alak esetében nem kerül sor. Az ün $[\mathrm{yn}]^{5}$ kiejtésű $U n$ - előtag jelentése 'hang, hírnév, tekintély'. A név ezek szerint a következőképpen értelmezhető: Unzat 'hírnévvel született, hírneves' (vö. még az analóg módon képzett oszmán-török harām-zat 'bünben született, fattyú' összetétellel). ${ }^{6}$

A dunai bolgár nyelv a nyelvtudományban leginkább elfogadott nézet szerint a türk nyelvek ogur ágához tartozik. A türk népek évszázadokon keresztül iráni kulturális hatás alatt álltak, amelyet nyelveik, többek között a dunai bolgár is tükröznek. A dunai bolgárban, amelynek elemei csekély számban maradtak fenn, magára a névre, valamint az összetétel két tagjára a források nem tartalmaznak adatot. Eddig a még egyetlen élő ogur nyelvben, a csuvasban sem találtam erre vonatkozó támpontot. Az $\ddot{u}[\mathrm{y}]$ hang ugyan létezik a csuvasban, ám úgy tünik, hogy a [z] és [3] zöngés réshangok — jelenlegi ismereteink szerint — csak jövevényszavakban fordulnak elő magánhangzó előtt. A csuvas mai nyelvállapota

\footnotetext{
${ }^{4}$ Azt felismerték, hogy az Unzat nem germán, s nem is szláv név, így valamely avar vagy török idiómából próbálták eredeztetni. Vannak szórványos értelmezési kísérletek, azonban egyik sem kielégítő. ZÖLLNER (1950: 262, 124. megj.) a nevet (tévesen Uzant alakban írva) a tör. uzun 'hosszú' jelentésű szóval hozza összefüggésbe.

${ }^{5} \mathrm{Az} \ddot{u}[\mathrm{y}]$ magánhangzóra az ófn.-ben nem volt külön graféma, pusztán $u$-ként jelölték. Az Uuozet alakváltozat az írásmód hallás utáni és írásbeli bizonytalanságát tükrözi.

${ }^{6}$ STEUeRWALd (1974: 974): ün: 1. 'hang, hangzás, kiáltás'; 2. 'hírnév, tisztesség, tekintély', a szóból képzett melléknév pedig az ünlü 'híres, tisztelt, megbecsült, tekintélyes'; 1281. old.: zat 'született', zati 'személyhez tartozó, személyt illető'. НАДжиП-РАхимовА (1968) az írásmódot (az Oroszországban szokásos módon) cirill betükkel és (kínai szokás szerint) arab betűkkel adja meg. Az átírás az arab ábécét követi. A [зат] (a Deutsch-Morgenländische Gesellschaft [DMG] átírásában: $z^{\prime} \mathrm{t}$ ) és [задә] (DMG: $z^{\prime} \mathrm{dh}$ ) írott alakok alatt pontosan ugyanaz a magyarázat szerepel, mégpedig magyarra fordítva a következő: „összetett szavak utótagjaként 'valamihez tartozó, valahol született' jelentésben". A - $t$ írásmód a szó végi mássalhangzó zöngétlen ejtésének felel meg (mint a törökben).
} 
azonban nem azonosítható a dunai bolgáréval. Általánosságban a dunai bolgár vonatkozásában is feltételezik az iráni hatást. Amennyiben a név ogur ágból történő eredeztetése nem szolgálna konkrét támponttal, gondolhatunk arra is, hogy valamilyen oguz-török idiómához rendeljük hozzá, ami azt is bizonyítaná, hogy a bolgárok és/vagy avarok között oguz-török csoportok is jelen voltak.

\section{A Pannónia dél-keleti részén feltételezett templomos helyek}

\subsection{Cella}

Unzat mint saját templommal rendelkező földbirtokos szerepel a Conversio 13. fejezetében, 865 körül (lásd fent). Már többen megkísérelték kideríteni, hol helyezkedhetett el az Adalwin által felkeresett Cella birtok, illetve település, ahol az említett templom várt felszentelésre. Cs. Sós (1973: 35-36, térkép, 6. ábra) a Cella nevet egy (Mohács melletti) Cselej-jel hozza összefüggésbe. Az e nézetet képviselő szerző bizonyára GYÖRFFY (Gy. 1: 293) adataira támaszkodott, amikor Cselej-t az 1236/1239-böl származó történeti forrás alapján — „cum essemus in domo Chelei prope Danubium”, azaz „amikor Chelei házában voltunk a Duna közelében" - arra a helyre teszi, ahol a Csele patak a Dunába torkollik, és a Chelei nevet viselő személyt annak névadójának gondolja. ${ }^{7} \mathrm{~A}$ név $-i$ végződése a településnévhez kapcsolt melléknévképző lehet, amely az egy adott településhez való tartozást jelöli; ez a település esetünkben Csele. E település neve a középkorban Csele és Cselej alakban váltakozva tünik fel, ez utóbbi névforma - $j$ helynévképzővel alakulhatott: a képzős és képző nélküli formák váltakozása meglehetősen gyakori volt a régiségben. A patak ugyancsak a Csele nevet viseli, de elnevezését valószínüleg a településről, és nem személyről kapta. A település minden valószínüség szerint a középkorban Mohácstól kb. 6 km-re északra (azaz a Dunától nem messze) létezett a mai Somberek határában a mai Cseli, Cselin, Csalina, Cselefalva, Csellefalva, sombereki ném. nyj. Tschalie [t $\mathrm{fa}$ 'li:] és további változatokban élő dülőnevek által jelölt területen (vö. BMFN. 2: 188). Az a tőhangzójú (disszimilált) alakok német nyelvjárási átnevezésekként értelmezendők.

A Cella Karoling-kor elötti földrajzi név, amely a vulg. lat./rom. *cella ['t $\mathrm{f} \varepsilon l a]$, esetleg ['t $\left.\int \varepsilon l e, t \int \varepsilon l: \mathfrak{e}\right]$ '1. a. kamra, b. pince, c. lépsejt; 2. kápolna, kis kolostor, szerzetesi cella' szóval áll kapcsolatban. A [ts] $>\left[\mathrm{t} \int\right]$ a keleti neolatin nyelvekben bekövetkezett hangváltozás és [1:] > [1] a vulgáris latinban bekövetkezett rövidülés. A magyar nyelv a magánhangzó-harmónia szabályai szerint vette át a szót, azaz $[\mathrm{a}]$ vagy $[\mathrm{e}]>[\varepsilon]$ változással, ami Csele $\left[' \mathrm{t} \int \varepsilon 1 \varepsilon\right]$ alakot eredményezett.

\footnotetext{
${ }^{7}$ A FNESz. a fent említett és további források alapján szláv személynévből eredezteti a Csele(j) helynevet.
} 
A középkorban a szomszédos Szebény (korábban Zebegény) községhez tartozó Zebegényföld puszta elnevezésü földrészleten Szent Mihály főangyalról nevezett bencés kolostor állt (vö. pl. 1251/1271: t. abb-is de Zubugun, 1278: t. mon-i de Zebeguen, 1346: Grisogono abb-e mon-i B. Mychaelis archangeli de Zebegen, Gy. 1: 408). Jóllehet a kolostor a 14. század közepén a Dunakanyarba (Visegráddal szembe) helyezte át székhelyét és ott a Zebegény helynevet továbbra is viselte, feltételezhetjük, hogy az azután is fennmaradt egykori kolostorépületben egészen a mohácsi csatáig spirituális élet folyt. A török korban a kolostor volt a török őrség székhelye. ${ }^{8}$ Ma már csak az alábbi képen látható rom emlékeztet rá.

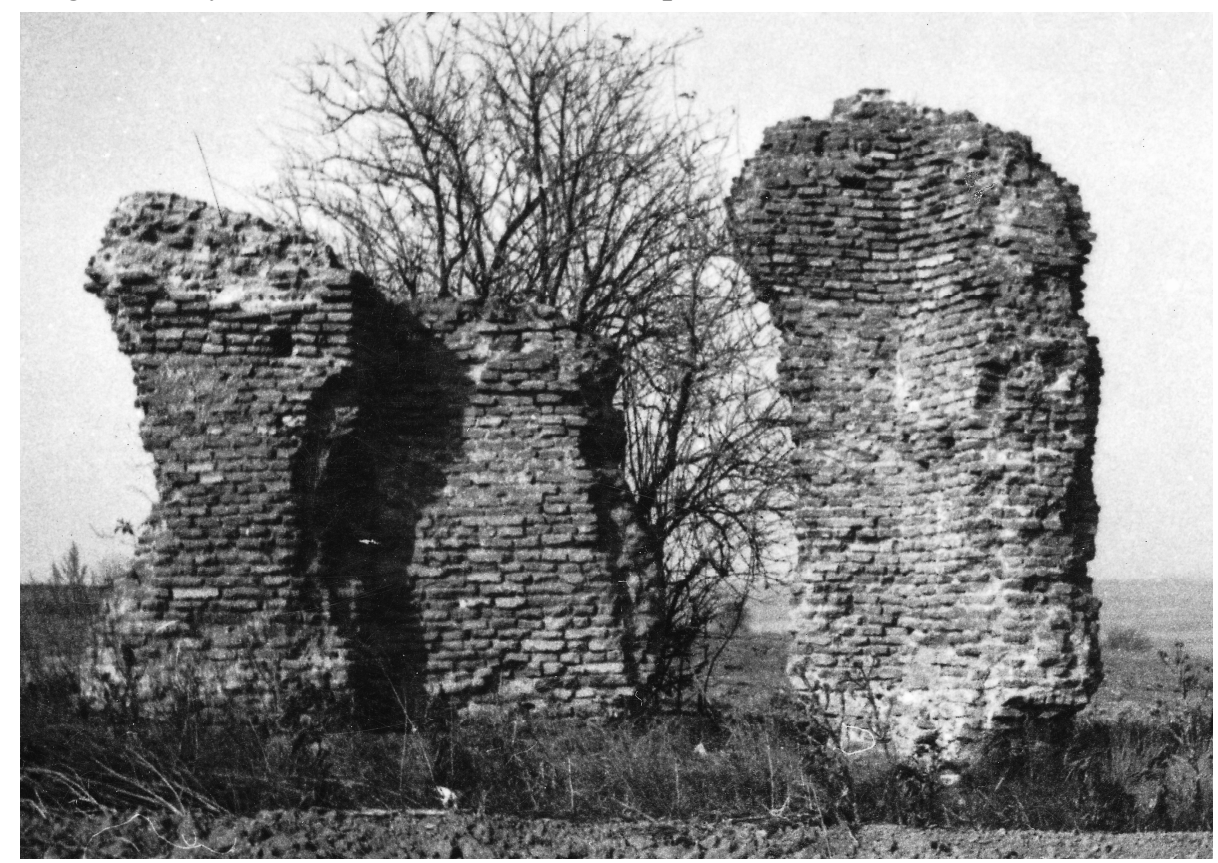

1. ábra. Az egykori zebegényi (később: szebényi) bencés kolostor romja a mai Somberek határában

A mai Csele dülőnévnek és változatainak a Karoling-korban már létező (általam a 2. jelentésváltozatban értelmezett) Cella helynévből történő eredeztetése,

${ }^{8}$ „Gálos Tomás házai, Báli kezében Szeben puszta határában a magas hüdzset (= török jogbiztosító irat) szerint kettő darab, Gvardiján háza, palotája a monostorban Szeben pusztán" (1591-ben keletkezett defter részlete, BMFN. 2: 109, Szebény). Dülőnevek: Gardianwiesen, Gardián Rétek stb. (BMFN. 2: 188, Somberek). A szó a tör. gardiyan 'őrség, ör' (STEUERWALD 397) átvétele. A terület korábban Szebényhez tartozott, ma Somberekhez (BMFN. 2: 188). GYÖRFFY a romban az egykori dobokai vár maradványát feltételezi (vö. Gy. 1:298), amire eddig nem találtam további támpontot (vö. BMFN. 2: 188). Az említett müben szereplő, adatközlőktől származó közlések szóbeli hagyományra támaszkodnak, egymástól eltérőek és részben ellentmondanak a történelmi tényeknek is. 
valamint a kolostor létezése az illető helyen megerősíti annak valószínüségét, hogy ott az ókeresztény korból származó szakrális hely állt, amelyet helyreállítottak, és amelyet Unzat előkészített az Adalwin általi felszentelésre. Az lehetséges volna, hogy a különböző hosszúságú téglák és a rom maradványai egy korábbi épület bontásából származnak. Ez is azt támasztaná alá, hogy a 9. századi templom a korábbi ókeresztény örökséghez kapcsolható. ${ }^{9}$ Annak alapján, hogy ezen a helyen kolostort létesítettek, feltételezhető, hogy a magyar honfoglalást követően is keresztények éltek itt.

\subsection{Termperch}

A Termperch (Thermberg) helynév nem tévesztendö össze a Német Lajos frank uralkodó 860. évi salzburgi adománylevelében (D LD.102) és a későbbi császári oklevelekben előforduló Ternperch névvel (vö. Tern-: szl. trbnb 'tövisbokor, sövény', SCHUSTER 1989: 391). E helynév valószínúleg a Balaton vidékén keresendő.

A Term- (vs. Tern-) előtag is más értelmezést kíván meg. A név egybecsengése a topográfiai lelettel amellett szól, hogy Termperch-et a mai Terehegy helynévvel hozzuk összefüggésbe. Terehegy Baranya megyében található, 1977-ben csatolták közigazgatásilag a termálfürdőjéről ismert szomszédos Harkányhoz.

A BMFN. szerint „A község a régi időben járhatatlan ingoványok közt emelkedett. Híd nélkül bele járni lehetetlen volt, ezért némi részben biztos lakhelyet adott. A helység közepén emelkedik egy domb, melyröl nem tudhatni, hogy a természet vagy emberkéz müve-é? melyen most a helység temploma áll. E domb mellett épület, fundamentumok és emberi csontok találtatnak. Igen hihetö, hogy a régi időben erösség volt itt. A[datközlőink] sz[erint] régen Teremhegy-nek is nevezték, mert jól termő vidék volt.” (2: 747, Terehegy). Az utolsó mondat igencsak naiv népetimológia, az adatközlő vagy a közlést feldolgozó személy kitalációja.

HAAS a következőképpen ír róla: „1823ban t. i. posványságok kiszáritása végett gróf Batthyányi Antal, mint a' falu' akkori földes ura, árkokat huzatván, némelly napszámosok, kik e’ posványos iszapos árkokban dolgoztak, 's már régóta

\footnotetext{
${ }^{9}$ A magyarok keresztény hitre térítése után röviddel megalapították az első bencés kolostorokat az ország területén. „Habár a letelepedéskor a bencés kolostorok helyének megválasztására vonatkozóan nem voltak elöírások, elmondható, hogy előszeretettel telepedtek meg olyan helyen, ahol már korábban is - akár pogány — szent hely létezett. (Szent Benedek első kolostora Subiacoban Néró elhagyott palotájában jött létre, Montecassino pedig korábbi pogány kultikus hely volt.) Pannonhalmáról azt tartja a hagyomány, hogy szent Márton imádkozott itt a ,mons sacer'-en és a közelben született. Zalaváron [Mosaburg] több templom és egy bazilika alapjait tárták fel. Pécsett [Quinque Basilicae > Quinque Ecclesiae] ilyenek az ókorból fennmaradt keresztény sírhelyek, Szombathelyröl [Savaria] ugyanez elmondható." (a pannonhalmi bencés apátság főapátja, Msgr. VÁRSZEGI ASZTRIK számomra megküldött, 2002.1.16-án kelt közlésének német fordításából).
} 
térdfájásban szenvedtek, — szembetünőleg érezték a' fölfakadott meleg források' jótékony hatását; melly esetet ők másoknak is elbeszélvén, számosan jelentek meg a' köznépből 's használták ezen iszapos meleg vizet fördésre. Az uraság látván az oda tolduló sokaságot, a' legbővebb forrást kitisztittatta és fördőszobákat állitván, közhasználatuvá tette." (1845: 333).

A helyszín felkeresésekor értesültem arról, hogy az idősek a szájhagyományból tudtak még kellemetlen kénes szagú meleg mocsarakról, amelyek télen sem fagytak be, és csak a talaj feltöltése után tüntek el. Erre az időszakra emlékeztet a nem messze található Büdös-tó dülő neve (BMFN. 2: 749).

A régészek longobárd fibulaleletekről és avarkori sírok feltárásáról számolnak be (BÁNDI szerk. 1979: 392, 398). Ezen felül a hely nem messze fekszik egy regionális római úttól, amely a római Antianae (Kö) - Nagyharsány - Siklós - Sopianae vonalon haladt (BÁNDI szerk. 1979: 293). A meleg mocsarak között kiemelkedő domb különösen a népvándorlás bizonytalan évszázadaiban szolgálhatott ideális menedékként. Ugyanezért építtette Pribina Mosapurc várát egy mocsarakkal körülvett, $s$ ezáltal védett magaslaton.

Az egykori lakosok számára kézenfekvő lehetett, hogy a helyet a két legfontosabb földrajzi jellemzője alapján nevezzék el; talán már a rómaiak is így tettek:

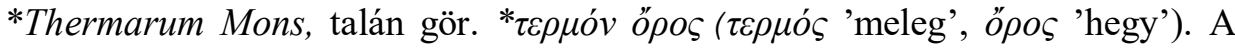
Conversio-ban elöforduló Termperch ennek ófn. megfelelöje volna, és elképzelhetö lenne, hogy a Conversio írnoka lefordította a nevet. A név elöfordul hibrid jövevényszóként (előtag: hangalak átvétele, utótag: tükörszó) *Teremhegy alakban; vö. 1332: p-em hereditariam Theremheg vel al. nom. Wruus vocatam in C-u Barana (Z. 1: 399-400, Gy. 1: 353), ${ }^{10}$ 1687: Ter hegye (BMFN. 1: 747), 1696: Terehegy (BMFN. 1: 1332). A Termperch vagy hasonló szóból történő származtatása egyszerú és valószínủ. A Term- > Terem- magánhangzó-betoldás megfelel a magyar nyelv hangtani adaptációs szabályainak. Hasonló átvételek: fr. berme és ném. nyj. perme $>\mathrm{m}$. perem '(út)padka',; ${ }^{11}$ alán $>$ oszét wärm $>\mathrm{m}$. verem 'verem, gödör, barlang' (TESz.); kfn., kném. turn, torn > m. torony (TESz.).

A Term- > Terem- hangzásbeli egybeesését nem értelmezem feltétlenül úgy, hogy a Terem- előtagot a népetimológia a magyar terem köznévvel azonosította, melynek régebbi jelentése 'ház, otthon, palota', de ez a lehetőség sem vethető el, különösen, hogy a magyar helynevekben a terem lexéma egyáltalán nem volt ritka. Valószínü azonban, hogy a Terem- előtag később nem rendelkezett a helybeliek számára azonosítható szemantikai tartalommal, különben a további hangfejlödés nem eredményezhette volna az 1696 óta adatolt, kötött és értelmezhetetlen Tere- morfémát.

\footnotetext{
${ }^{10}$ E névalak, amelyet GYÖRFFY a Palotabozsok mellé lokalizált Feloros egyszeri előfordulású névváltozataként említ, újabb kori adatolás híján további vizsgálatokat igényel.

${ }^{11}$ A TESz. a perem szót a kfn. brëm-ből eredezteti.
} 
Az elötag másként — Term- 'terminus, határ' jelentésben — történő értelmezése kizárható, mivel ez a szó, amennyire sikerült megállapítanom, az ófn. szótárakban nem fordul elö. A -hegy, illetve korábbi alakban heg utótag (ahol az írásmód a palatalizációt nem tükrözi) a ném. 'Berg' szó megfelelője.

Szent Lörinc patrocíniuma GYÖRFFY szerint nem ritkán római folytonosságra utal (KLEBEL 1928: 376). A helynév értelmezése alapján ugyan feltételezhető, de a régészet mindeddig nem bizonyította, hogy a helyen Karoling-kori templom vagy azt körülvevő sírkert lett volna. Szent Lörinccel mint névadóval csak a mintegy 30 km-re fekvő Szentlőrincen találkozhatunk a 13. századtól kezdődően, amely elnevezés eredetileg a templomos lovagrend kolostorának templomát jelölte. Ez a körülmény indította KLEBELt arra, hogy Termperch-et a Baranya megyei Szentlörinccel hozza összefüggésbe (HWb. Grenzdeutschtum 672, 114 térkép. Nyugat-Magyarország a 9. században, KLEBEL Összeállítása alapján). BOGYAY és CS. Sós Termperch-et a Balaton környékén feltételezik (valószínüleg azért, mert azonosítják Ternperch helynévvel, amely az előzőekben kifejtettek szerint a Balaton környékén létezett).

\section{3. Összegzés}

A 9. század 60-as évei a nagy átalakulások időszakát jelentették Pannónia keleti szélén. A szomszédos Bolgár Birodalomban a lakosság nagy része már keresztény hitre tért, a Duna innenső oldalán e folya mat valószínűleg még inkább előrehaladott volt. I. Borisz bolgár uralkodó 863-ban keresztelkedett meg bizánci rítus szerint, ám nem sokkal később már Rómához fordult azzal a kéréssel, hogy küldjenek országába alkalmas papokat és püspököket. Borisz és Német Lajos tárgyaltak a morvák elleni szövetségről, ennek során Tullnban találkoztak egymással, és szóba került a keresztény hittérítés terén nyújtandó támogatás is. A salzburgi érsekség e területen kifejtendő missziós tevékenységének előfeltételeit csak a keresztény hitnek a helyi lakosság (szlávok, avarok) körében történő még nagyobb elterjedése, valamint a politika alakulása teremtette meg; Adalwin az így kínálkozó lehetőséget viszonylag rövid időtartamban használta ki térítő tevékenységre.

Azt, hogy a kereszténység nem halt ki az avar kor végére, alátámasztják a szóban forgó területen fellelt keresztény szimbólumok is (vö. TÓTH E. 2013). ${ }^{12}$ Pribina szláv fejedelemsége nagyobb kiterjedésủ volt, mint eddig feltételeztük, és lehetséges, hogy Unzat mint földbirtokos messzemenő önállósággal rendelkezett a keleti területen. Származása és neve alapján valószínüleg erősebb kapcsolata lehetett a nem szláv (avar vagy bolgár) lakosság maradványaival.

\footnotetext{
${ }^{12}$ A tanulmányban a szerző többek között egy Görcsönydobokáról származó korongfibulát is tárgyal, melynek képét is közli.
} 


\section{Irodalom}

BÁNDI GÁBOR szerk. 1979. Baranya megye története az öskortól a honfoglalásig. Pécs, Baranya Monográfia Sorozat.

Bethmann, C. L. 1887. Die Evangelienhandschrift von Cividale. Neues Archiv für ältere deutsche Geschichtskunde 2: 111-128.

BMFN. = PESTI JÁNOS szerk. 1982. Baranya megye földrajzi nevei I-II. Pécs, Baranya Megyei Levéltár.

Bogyay, THOMAS von 1960. Die Kirchenorte der Conversio Bagoariorum et Carantanorum. Methoden und Möglichkeiten ihrer Lokalisierung. Südost-Forschungen 19: $52-70$.

Conversio = lásd WOLFRAM, HeRWIG 2013.

D LD.102 = Die Urkunden der Deutschen Karolinger. Reichsinstitut für ältere deutsche Geschichtskunde. Szerk. KEHR, PAUL. $-1 .=$ D LD = Die Urkunden Ludwigs des Deutschen. Berlin, 1934. Különösen a 102. oklevél, 147.

FNESz. = KISS LAJOS 1988. Földrajzi nevek etimológiai szótára I-II. Negyedik, bövített és javított kiadás. Budapest, Akadémiai Kiadó.

Gy. = GYÖRFFY GYÖRGY 1963-1998. Az Árpád-kori Magyarország történeti földrajza $I-I V$. Budapest, Akadémiai Kiadó.

HAAS MihÁly 1845. Baranya földirati, statisticai és történeti tekintetben. Pécsett.

KLEBEL, ERNST 1928. Die Ostgrenze des Karolingischen Reiches. Jahrbuch für Landeskunde von Niederösterreich 21: 348-380.

MitTerauer, Michael 1960. Slawischer und bayerischer Adel am Ausgang der Karolingerzeit. Carinthia I 150: 693-726.

НАДжиП, Э. Н.-РАХимовА, Т. Р. 1968. Уйгурско-русский словарь. Москва, Рипол Классик.

SCHUSTER, ElisABETh 1989. Die Etymologien der Niederösterreichischen Ortsnamen. Historisches Ortsnamenbuch von Niederösterreich 8. Wien.

Cs. Sós, ÁGNES 1973. Die slawische Bevölkerung Westungarns im 9. Jahrhundert. Münchner Beiträge zur Vor- und Frühgeschichte 22. München, C. H. Beck'sche Verlagsbuchhandlung.

STEUERWALD, KARL 1974. Türkisch-Deutsches Wörterbuch. Wiesbaden, Harrassowitz.

TÓTH ENDRE 2013. Titkos keresztények az avar korban. In: TóTH ORSOLYA-FORISEK PÉTER szerk. Ünnepi kötet Gesztelyi Tamás 70. születésnapjára. Debrecen, A Debreceni Egyetem Történelmi Intézete. 203-220.

Wolfram, Herwig 2013. Conversio Bagoariorum et Carantanorum. Das Weißbuch der Salzburger Kirche über die erfolgreiche Mission in Karantanien und Pannonien mit Zusätzen und Ergänzungen. Harmadik, alaposan átdolgozott kiadás. Ljubljana-Laibach, Hermagoras Verlag.

ZÖLLNER, ERICH 1950. Awarisches Namensgut in Bayern und Österreich. Mitteilungen des Instituts für Österreichische Geschichtsforschung 58: 244-266. 


\section{Was the Eastern Part of Pannonia Also Under Carolingian Rule in the $9^{\text {th }}$ Century?}

Recent archaeological excavations have confirmed the formerly disputed question that during the $9^{\text {th }}$ century the extensive area of Pannonia was under Carolingian rule. The paper further substantiates this finding with the examination of documents related to the missionary activities of the Archdiocese of Salzburg, thus confirming that the rule of the Carolingian Dynasty extended all the way to the Danube and Drava. In the $13^{\text {th }}$ chapter of Conversio, we can find data that in 865 Archbishop Adalwin consecrated churches in this area as well.

In connection with this, the text mentions a squire named Unzat with his own church, whose name had already appeared in earlier documents as well. Publications have already established that he could be the son of Pribina, however, the origin of his name could not be explained. The paper explains the Unzat personal name with hybrid compounding, with the meaning 'born with fame'. The first constituent could be the Danubian Bulgarian $\ddot{u} n$ [yn], with the $z \bar{a} d \sim z \bar{a} d e$ second constituent attached to it, which was ultimately of Iranian origin appearing at several places in Turkic languages.

The church of Unzat was located on an estate called Cella. This name originates from the times prior to the Carolingian era, and it derives from the vulgar Latin *cella 'chapel, monastic cell' word. By means of regular phonological changes, the name assumed the Csele form in Hungarian, and this name still exists today close to Szebény (formerly Zebegény) village, where a Benedictine monastery used to stand.

The place called Temperch, also mentioned in Conversio, can also be localized in Baranya County, and it can be identified with the name of Teremhegy settlement belonging to Harkány today. The former Latin name of this place known for its hot water springs could be *Thermarum Mons, while Temperch could be its Old High German counterpart, which could be created as a result of a partial translation by a scribe (by translating the second constituent), similarly to the Hungarian Teremhegy name form. 